\title{
Relationship Between Mindfulness and Grit Among Final Year Students in Makassar City
}

\author{
${ }^{1}$ Psychology Department, Faculty of Medicine, Hasanuddin University \\ ${ }^{2}$ Psychology Department, Faculty of Medicine, Hasanuddin University \\ ${ }^{3}$ Psychology Department, Faculty of Medicine, Hasanuddin University \\ *Corresponding author. Email: christopherstenly@gmail.com
}

Stenly Christopher ${ }^{1, *}$, Umniyah Saleh ${ }^{2}$, Andi Tenri Pada Rustham ${ }^{3}$

\begin{abstract}
College students, who are working on their final assignments, need the grit to complete their studies well. However, there are still students who have low grit levels, so that not just a few students experience delays in completing their studies, even until they are dropped out of college. Mindfulness, which has the characteristics of being aware of itself, both in place and mentally, to the circumstances that occur at that moment, can help students refocus on their goals to complete their studies well. This study investigated the relationship between mindfulness and grit on final year students in Makassar. This study used a quantitative method with a correlational design. The subjects of this study were 183 last year students who are working on their final assignments at the top three public universities in Makassar City, namely Hasanuddin University, Makassar State University, and Alauddin State Islamic University Makassar. Data were analyzed using bivariate Person correlation, and the result indicated that mindfulness is significantly correlated with grit. The relationship between mindfulness and grit in this study was adequate with a correlation coefficient $r(183)=0.352, p<0.05$, indicating that the higher the mindfulness, the higher the grit, and vice versa. This showed that students who were undergoing the educational process in higher education should have attention and awareness in undergoing the educational process so that these students could achieve their long-term goals.
\end{abstract}

Keywords: Mindfulness, grit, final year students

\section{INTRODUCTION}

A college student was undergoing a learning process and registered in one form of college in Indonesia called: akademik; politeknik; sekolah tinggi; institut; and universitas [1]. According to Permendikbud Number 3 of 2020 about National Standards for Higher Education, undergraduate students have a maximum study period of seven years. Thus, students who cannot complete their studies in specific periods will drop out of college.

College students in Indonesia usually complete a study consisting of at least 144 credits for approximately four years. It means a student with a seven-year maximum study period will have about three more years to complete the study. Even so, There are students who could not complete within seven years and drop out.

In Aditya Sukma's research [2], study completion delays in students are significantly influenced by learning behavior and academic stress. In line with this research, Raharjo [3] found that students did not complete their studies on time due to academic, moral, financial, organizational, and other technical problems. In addition to these five problems, some students do majors not on their initiative. It can make these students unable to feel the scientific basis since they first entered college and have academic problems. This claim follows Raharjo ${ }^{\text {'s] }}$ findings that $20 \%$ of students took majors not on their initiative.

In reality, the process that occurs in higher education cannot be separated from various problems, obstacles, and challenges. However, as students who have a goal to graduate well, they should survive when facing these problems, obstacles, and challenges to realize their goals. The authors found that the behavior of students who can survive while facing issues, obstacles, and challenges to realize their long-term goals is characteristic of individuals who have a high grit level.

Grit is a form of a personality trait that is an individual's tendency to maintain perseverance and interest in achieving challenging long-term goals. Each individual persists with these things until they 
reach their final goal [4]. Growing grit requires consistency of interest and perseverance of effort [4]. In the context of this study, they were students who have a high grit level, which will impact their ability to fight for their goals despite obstacles, challenges, and failures. This statement is in line with Winarto et al.'s [5] research, which states that students who complete their studies on time have an excellent grit picture in carrying out their study process.

Based on the explanation of grit above, students should have a high grit level to achieve their goal to graduate well. However, the results of Izaach's research [6] showed that most of the students, 44 out of 51, have a low level of grit. Rosyadi \& Laksmiwati [7] also found that 27 students had low grit levels. The students with high grit will not be easily distracted from their primary goal. Students become more organized and focused on the goals they want to achieve. Thus, it can be seen that this grit is essential for students to pursue higher education.

Duckworth [8] said that grit could be grown from the inside out (interests, practice, goals, and hopes) and from the outside (parenting, playing field, culture). In order to grow grit from the inside out, individuals are expected to develop interest, do lots of exercises, set good intentions or goals, and have hope or be optimistic. Developing self in these four parts can be quickly done if the individual has mindfulness - living the "present time" with full attention and total awareness [9].

Behaving based on interest is essential to growing grit, especially for passion. With awareness, individuals can respond to stimuli or act according to their interests and values [10]. In their writings, Deci et al. [10] asserted that high-quality awareness made individuals more connected to one's needs, feelings, interests, and values. Without awareness, individuals are less able to behave following their authenticity.

Doing much practice to grow grit can also be done with the strategy of "self-awareness without judgment" [8]. When individuals break away from judgment, they can enjoy the current and future challenges. Most people do not want to enjoy the exercise challenge because they cannot escape the judgment that can disturb the processes in the middle of the individual's exercise.

Setting goals is one of the fuels that are also important in growing grit. Most people with a high grit see purpose as being connected to the world outside themselves. Deci et al. [8] said that awareness helps individuals choose goals well and in accordance with their authentic selves. McCarthy [11], in his research, also showed that goal achievement-oriented individuals are more mindful individuals.
Hope or an optimistic attitude in the form of efforts to improve the future is essential in growing grit [8]. One way to increase one's hopes can be done by doing mindfulness meditation exercises [12]. Black [13], in the book "Handbook of Mindfulness" also writes that mindfulness has a psychosocial impact, one of which is positive emotions (joy, hope, and pride).

Duckworth [8] also explained that the more gritty individuals with long-term stamina tend to have goals with intrinsic values. It is in line with selfdetermination theory which states that people try harder and show a higher level of perseverance when they do what they love and find meaning for it than when they are purely rewarded or external means such as money [14]. This claim was later confirmed by K. Aryanto [15], which found that people with an internal locus of control have higher grit levels than those with an external locus of control. Then linking the theory of self-determination with the construct of mindfulness, Deci et al. [10] said that when a person is aware of what is happening internally and externally, they can make better choices and engage in a compatible and authentic behavior.

Mindfulness was originally a religious meditation practiced by Buddhists. This meditation was later adapted into the field of psychology by Kabat-Zinn. Mindfulness is defined as the ability to focus attention directly, openness to experience, over time, with openmindedness and self-acceptance [16].

Mindfulness is also often applied in educational settings. The findings in educational settings show that mindfulness can increase the optimization of the educational process. Matt Leland [17] found that mindfulness has a relevant and potentially important role in education, based on academic performance, critical thinking skills, student self-control, and other characteristics. Thus, the study of mindfulness variables in educational settings in Indonesia can be a form of the initial solution.

In addition to increasing the optimization of the educational process, mindfulness can also help students increase their chances of achieving goals, that is, to graduate. It is in line with what Bränström et al. [18] wrote that mindfulness could increase the possibility of controlling his behavior and making behavioral decisions that lead to achieving goals.

Mindfulness turns out to have a role in helping students have good performance in completing all processes in higher education. However, in reality, mindfulness is less visible in some students. Suhadianto \& Arifiana [19], in their research, showed that there were 106 students, or $23.55 \%$, who had low to very low mindfulness levels. From this research, Suhadianto \& Arifiana [19] stated that there is still a 
need for efforts to increase mindfulness in students because mindfulness has a positive influence on psychological well-being and academic success. Thus, increasing mindfulness in students can create a state of attention and awareness of what is happening in the present [9].

So, based on the description above, the author was interested in examining the relationship between mindfulness and grit on final year students in the city of Makassar. It is also important to research because the number of studies that discussed or linked these two variables was still limited, especially in Indonesia, especially in Eastern Indonesia. The author hoped that this research could describe a statistical relationship between the two variables, which could develop further research ideas to develop education in Indonesia, especially in Eastern Indonesia.

\section{METHOD}

\subsection{Respondent}

The respondents in this study were final year students working on their final assignments at the top three public universities in Makassar city, namely Hasanuddin University, Makassar State University, and Alauddin State Islamic University $(n=183)$. In this study, respondents will be given a questionnaire via google form to measure respondents' mindfulness and grit levels.

\subsection{Measurement}

\subsubsection{Dependent variable}

The respondents' grit levels were obtained using the grit scale compiled by Duckworth [4] and used in Aidil Aryanto K.'s [15] research. This scale contains 12 items. From the 12 items, six items measure the respondent's consistency of interest, and the other 6 measure the respondent's perseverance of efforts. This scale shows a correlated item-total of 0.244-0.647 (valid, more than R-table $0.148 \quad(n=175$; the level of significance 5\%)) and a reliability coefficient of Cronbach's alpha of 0.719 (reliable).

\subsubsection{Independent variable}

The respondents' mindfulness levels were obtained using the mindful attention awareness scale (MAAS) compiled by Brown \& Ryan [9] and adapted by the authors. In the process of adapting the measuring instrument, the authors use the MAAS measuring instrument that has been used by Nurida and Widyasari's [9] research as a reference. This scale contains 15 items (unidimensional). This scale shows a correlated item-total of 0.390-0.766 (valid, more than R-table $0.148(n=175$; the level of significance $5 \%)$ ) and a reliability coefficient of Cronbach's alpha of 0.856 (reliable).

\subsection{Statistic Methods}

The data in this study were analyzed using Ms. Excel 2010 for descriptive statistical testing in obtaining descriptive data of the level of mindfulness and grit in final year students in the city of Makassar, and IBM SPSS 24 for testing inferential statistics to see the strength of the relationship between mindfulness and grit variables in the Pearson correlation test.

\section{RESULT}

\subsection{Descriptive Statistics}

The following table shows that the respondents of this study were dominated by females $(63 \%)$ and students from Hasanuddin University (36\%). The age of the respondents in this study was in the range of 20 to 26 years old. Based on the following table, it was also found that the average (mean) grit score of the whole respondents was 39.46 with a standard deviation of 6.51 , and the average (mean) mindfulness score of the whole respondents was 59.16 with a standard deviation of 12.23 .

Table 1. Descriptive statistics

\begin{tabular}{|c|c|c|c|}
\hline Variables & Mean (SD) & Range & $\%$ \\
\hline \multicolumn{4}{|l|}{ Gender } \\
\hline Male & & & 37 \\
\hline Female & & & 63 \\
\hline \multicolumn{4}{|l|}{ Universities } \\
\hline Unhas & & & 36 \\
\hline UNM & & & 35 \\
\hline UIN-AM & & & 29 \\
\hline Ages & $22.20(1.10)$ & $20-26$ & \\
\hline Grit & $39.46(6.51)$ & $21-55$ & \\
\hline
\end{tabular}




\begin{tabular}{lcc}
\hline Cons. of Interest & $17.29(4.55)$ & $6-29$ \\
\hline Pers. of Effort & $22.16(3.89)$ & $10-30$ \\
\hline Mindfulness & $\begin{array}{c}59.16 \\
(12.23)\end{array}$ & $29-89$
\end{tabular}

SD = Standard deviation; Unhas = Hasanuddin University; $\mathrm{UNM}=$ Makassar State University; UIN-AM = Alauddin State Islamic University; Age Unit = Years; Grit $=$ The higher the score, the higher levels of grit; Mindfulness $=$ The higher the score, the higher levels of mindfulness.

\subsection{Pearson Correlation}

The following are the results of the Pearson correlation test for mindfulness and grit variables on the IBM SPSS 24.

Table 2. Correlation analysis

\begin{tabular}{llll}
\hline \multirow{2}{*}{ Mindfulness } & \multicolumn{1}{c}{ Mindfulness } & Grit \\
& $\begin{array}{l}\text { Pearson } \\
\text { Correlation }\end{array}$ & 1 & $.352^{* *}$ \\
\cline { 2 - 4 } & $\begin{array}{l}\text { Sig. (2- } \\
\text { tailed) }\end{array}$ & .000 \\
\hline Grit & $\begin{array}{l}\text { Pearson } \\
\text { Correlation }\end{array}$ & $.352^{* *}$ & 1 \\
\cline { 2 - 4 } & $\begin{array}{l}\text { Sig. (2- } \\
\text { tailed) }\end{array}$ & .000 & \\
\hline & $\mathrm{N}$ & 183 & 183 \\
\hline
\end{tabular}

The table above shows the Pearson bivariate correlation test results on the two variables, namely mindfulness and grit, with 183 respondents. Sig. value (2-tailed) from the results of the Pearson mindfulness bivariate correlation with grit is $0.000(<0.05)$, and Rvalue is $0.352 * *$ and has a positive value, which means that the higher mindfulness, the higher grit, and vice versa.

The test results are then interpreted by looking at the sig value. (2-tailed) between two variables, if the significance value is less than 0.05 , there is a relationship between variables. In the table, the value of sig. (2-tailed) mindfulness with a grit of 0.000 $(<0.05)$. It shows that there is a significant relationship between mindfulness and grit. There is also an R-value from the Pearson bivariate correlation test. Suppose it is greater than the R-table (a reference to determining the $\mathrm{R}$-value per respondent's value). In that case, it means a relationship between the variables being tested. In testing the mindfulness variable and grit hypothesis, the $\mathrm{R}$-value is $0.352^{* *}$, more significant than the minimum value in the R-table, which is 0.148 (from the distribution table for the R-value). Thus, it can be concluded that there is a relationship between the grit variable and the mindfulness variable.

The following are the results of the Pearson correlation test for mindfulness and grit variables based on their dimensions on the IBM SPSS 24.

Table 3. Correlation analysis based on dimensions

\begin{tabular}{|c|c|c|c|c|}
\hline & & $\begin{array}{l}\text { Mindfu } \\
\text { lness }\end{array}$ & $\begin{array}{l}\text { Grit - } \\
\text { Cons. } \\
\text { Interest }\end{array}$ & $\begin{array}{l}\text { Grit- } \\
\text { Pers. } \\
\text { Effort }\end{array}$ \\
\hline \multirow[t]{2}{*}{$\begin{array}{l}\text { Mindful } \\
\text {-ness }\end{array}$} & $\begin{array}{l}\text { Pearson } \\
\text { Correlation }\end{array}$ & 1 & $.529 * *$ & -.030 \\
\hline & $\begin{array}{l}\text { Sig. (2- } \\
\text { tailed) }\end{array}$ & & .000 & .686 \\
\hline \multirow{2}{*}{$\begin{array}{l}\text { Grit } \\
\text { (Cons. } \\
\text { Interest) }\end{array}$} & $\begin{array}{l}\text { Pearson } \\
\text { Correlation }\end{array}$ & $.529 * *$ & 1 & $.183 *$ \\
\hline & $\begin{array}{l}\text { Sig. (2- } \\
\text { tailed) }\end{array}$ & .000 & & .013 \\
\hline \multirow{2}{*}{$\begin{array}{l}\text { Grit } \\
\text { (Pers. } \\
\text { Effort) }\end{array}$} & $\begin{array}{l}\text { Pearson } \\
\text { Correlation }\end{array}$ & -.030 & $.183^{*}$ & 1 \\
\hline & $\begin{array}{l}\text { Sig. (2- } \\
\text { tailed) }\end{array}$ & .686 & .013 & \\
\hline & $\mathrm{N}$ & 183 & 183 & 183 \\
\hline
\end{tabular}

The table above shows the Pearson bivariate correlation test results on mindfulness (unidimensional) and grit dimensions, with 183 respondents. Sig. value. (2-tailed) from the results of the Pearson mindfulness and grit bivariate correlation test on the dimension of consistency of interest is 0.000 . Meanwhile, the dimension of perseverance of effort is 0.686 . The $\mathrm{R}$-value shown in the table above is for mindfulness and grit on the dimension of consistency of interest was $0.529 * *$, which is positive, while the dimension of perseverance of effort is 0.030 , which is negative.

In the table, the value of sig. (2-tailed) mindfulness and grit on the dimension of consistency of interest were $0.000(0.05)$, which can be interpreted as no significant relationship between mindfulness and grit on the dimension of perseverance of effort. So, it can be concluded that there is a significant relationship between mindfulness and grit on the dimension of consistency of interest, and there is no significant relationship between mindfulness and grit on the dimension of perseverance of effort. 


\section{DISCUSSION}

This study aims to determine whether or not there is a relationship between mindfulness and grit in final year students in Makassar City. Based on the results of research conducted by authors, it was found that there was a significant relationship $(0.000<0.05)$ between mindfulness and grit in final year students in the city of Makassar with a correlation coefficient of 0.352 , which was positive. The correlation coefficient value is included in the criteria for sufficient correlation strength. The results of this correlation indicate that the higher respondents' level of mindfulness, the higher the grit level of respondents, and vice versa.

Mindfulness is a disposition of the presence of individual awareness that is inherent and involves experience from time to time [9]. Individuals who have a high level of mindfulness have the characteristics of being aware of themselves, both physically and mentally, of the situation that is happening at that moment and not thinking or fixating on past and future events, but focusing on the present situation [21]. Meanwhile, grit is an individual's tendency to maintain passion and perseverance in achieving and maintaining long-term goals [4]. Grit requires hard work to meet challenges, maintain effort and interest despite failure in the process. There are two essential things in grit: consistency of interest and perseverance of effort [4].

Duckworth [8], in his book, wrote that grit can be grown from the inside out through the variables of interests, practice, goals, and hopes that can fuel the inside out. Finding interest, doing lots of exercises optimally, setting good intentions or goals, and having hope and optimism can be achieved if the individual is mindful of living his experience from time to time[8,10,11,12,13].

Duckworth [8] also explained that the goals of more gritty individuals with long-term stamina tend to have intrinsic value. This explanation is in line with self-determination theory which states that individuals can try harder and show a higher level of perseverance when they do what they like and find meaning than when they are purely rewarded or other external means such as money. (Ryan \& Deci, 2000). One way to find intrinsic value can be done by increasing selfawareness, which is one of the constructs of mindfulness. Individuals can consciously make choices and engage in compatible and authentic behavior.

In addition, individuals who have higher levels of mindfulness will be able to direct their attention away from stressors towards thoughts such as, "Instead of worrying and contemplating about yourself, it is better to have high hopes by concentrating on the current situation to see what needs to be done" [22]. Supporting the ideas of Snyder [22], Munoz et al. [12] showed that interventions with mindfulness meditation make individuals have higher hopes. These hopes make one's mindfulness able to increase one's grit.

In addition, mindfulness can also provide an important foundation for grit by increasing one's selfregulation. According to Bandura [23], self-regulation is how humans can regulate themselves, influence their behavior by regulating the environment, creating cognitive support, and carrying out consequences. This role of self-regulation has important implications for grit because, during the pursuit of long-term goals, the person is likely to encounter short-term hedonic goals but conflict with long-term goals. For example, students with a long-term goal of getting a cum laude degree. The exam schedule will be held tomorrow, but the student is invited to his friend's party. If the student can mindfully observe their desire to go out and have fun, in that case, it can delay him from automatically saying "yes" and leave room for a more reflective and adaptive response, i.e., choosing to stay home and study for his exams. Therefore, in theory, mindfulness has a relationship with grit by protecting individuals from being distracted by short-term temptations and remaining faithful to work towards long-term goals [24].

The research results in this study are in line with research conducted by Raphiphatthana, Jose, \& Chobthamkit [25], which showed that there was a positive relationship between mindfulness and grit, both for students in New Zealand and among students in Thailand. Through their research, Vela et al. [26] found similar results that hope and mindfulness are significant predictors of grit in Latina/o College students. Then research conducted by Rusadi, Sugara \& Isti'adah [27] found, in their experimental research, that Mindfulness-based Cognitive Therapy (MBCT) was significantly able to increase grit in students. 
Thus, the results of this research are in line with previous research.

The correlation coefficient of 0.352 found in this study means that the relationship between mindfulness and grit is $35.2 \%$ and other variables related to grit are $64.8 \%$. Other variables that may be related to grit include the optimism variable, which was found to have a very strong $(\mathrm{R}$-value $=0.710)$ and significant $(\mathrm{p}<0.05)$ correlation with grit [28]. The adjustment variable was found to have a strong correlation ( $\mathrm{R}$ value $=0.596)$ and significant $(\mathrm{p}<0.05)$ with adjustment [29]; Subjective well-being variables were found to have a strong correlation $(\mathrm{R}$-value $=0.500)$ and significant $(\mathrm{p}<0.05)$ with grit ${ }^{[7]}$. Thus, it can be concluded that mindfulness is one of the variables related to grit. Other variables were not examined by the author, which is related to grit.

In addition to finding out whether or not there is a relationship between mindfulness and grit, the authors also looked at the relationship between mindfulness (unidimensional) and grit's dimensions: consistency of interest and dimensions of perseverance of effort. Based on the results of the Pearson bivariate correlation test conducted by the authors, the authors found that mindfulness had a strong $(\mathrm{R}$-value $=0.529)$ and significant relationship $(0.000<0.05)$ with grit on the dimension of consistency of interest. Meanwhile, the author did not find any significant relationship $(0.686>0.05)$. Thus, it can be concluded that the mindfulness of final year students in Makassar City has a relationship with grit on the consistency of interest dimension but does not have a relationship with the perseverance of effort dimension.

High consistency of interest is described in individuals who show the ability to maintain interest in the direction of their long-term goals, where this will not change the goals they have set [8]. Meanwhile, high perseverance of effort is depicted in individuals who show their ability to complete work. In addition, individuals who have the perseverance of effort can face challenges and obstacles, work hard, and continue to strive to achieve goals [8].

Behaving based on interests is important to grow grit, especially in the passion section, which is measured through the consistency of individual interests. Individuals with awareness can respond to stimuli or behave according to their interests and values [10]. Awareness helps individuals choose goals and in accordance with their authentic selves. When individuals know their goals and find their authentic selves, they will undoubtedly find it easier to find their interests. Students who have found their interests in line with their goals and authentic selves will not exhibit conflicting interests.

The existence of a strong relationship between mindfulness and grit on the dimension of consistency of interest, in this study, is in line with research conducted by Bränström et al. [18], who found that mindfulness can increase the probability of a person to control his behavior and make the decision to achieve his goals. Unlike the previous study, the authors found no correlation between mindfulness and perseverance of effort in grit in this study by Buaphrao, Jose, \& Chobthamkit [25]. However, Raphiphatthana, Jose, \& Chobthamkit [25] linked mindfulness, measured using the Five Facet Mindfulness Questionnaire (FFMQ), with grit. The study found that the mindfulness of Thai students on the dimensions of act-awareness, nonreacting, and describing was related to grit on the dimensions of perseverance of effort. For New Zealand students' mindfulness, the dimensions of actawareness, non-reacting, non-judging, and describing were related to grit on the dimensions of perseverance of effort. Raphiphatthana, Jose, \& Chobthamkit [25] showed that most mindfulness dimensions were related to grit in the perseverance of effort dimension. There is also a mindfulness dimension that did not have a significant relationship with grit on the consistency of interest dimension. In Thai students, mindfulness on the non-judging and observed dimensions did not significantly correlate with grit on the perseverance of effort. Furthermore, for New Zealand students, mindfulness on the observed dimension did not significantly correlate with grit on the perseverance of effort dimension.

The differences in the results in this study may be influenced by different cultural backgrounds, as found by Raphiphatthana, Jose, \& Chobthamkit [25]. The study showed that mindfulness had a stronger relationship with grit in individualistic societies than in collectivist societies. As is well known, Indonesian people, especially Eastern Indonesia, still have quite strong collectivist values. 


\section{CONCLUSION}

Based on the results and discussion of this study, we can conclude that there is an adequate and significant relationship between mindfulness and grit in final year students in the city of Makassar. It indicates that the higher the mindfulness, the higher the grit, and vice versa. Furthermore, the results of this study also show that mindfulness is related to a strong and significant level with grit on the consistency of interest. While the relationship between mindfulness and grit on the perseverance of effort was found, there was no significant relationship.

\section{STUDY LIMITATION}

The limitation of this study was that this research was conducted during the COVID-19 pandemic, so that data collection was carried out through an online survey called Google Form. It had caused the authors to ensure that respondents filled the research scale with a proportional environment and circumstances. The environment and circumstances that were not proportional could lead to the possibility that the filling of the research scale did not match the actual condition of the respondent.

\section{AUTHORS' CONTRIBUTIONS}

Author 1 was conceived the idea of the research's topic and designed the analysis, collected data, contributed analysis tools, and performed the analysis. While authors 2 and 3 supervised all the research progress, they also conceived the idea of the research's topic and design analysis. All authors discussed the results and contributed to the final manuscript.

\section{ACKNOWLEDGMENTS}

We thank all the respondents who have agreed to participate in this study fully. We are also grateful for guidance and feedback from Dr. Ichlas Nanang Affandy, S.Psi., MA, and Triani Arfah, S.Psi., M.Psi., Psikolog. This work was supported by Psychology Department, Faculty of Medicine, Hasanuddin University and was done under the ethical code of psychology from Himpunan Psikologi Indonesia (HIMPSI).

\section{REFERENCES}

[1] Hartaji, Damar A. Motivasi Berprestasi Pada Mahasiswa yang Berkuliah Dengan Jurusan Pilihan Orang Tua. Jakarta: FPsi Gunadarma; 2012

[2] Sukma, Aditya. Studi Empiris Pengaruh Kecerdasan Emosional, Perilaku Belajar, dan Stres Kuliah terhadap Keterlambatan Penyelesaian Studi (Studi pada Mahasiswa S1 Akuntansi Universitas Brawijaya Malang). Jurnal Ilmiah Mahasiswa FEB. 2013; 1(2).

[3] Raharjo. Problem dan Solusi Studi Mahasiswa Semester Tua. Jurnal Pendidikan Islam. 2014.

[4] Duckworth, A. L., Peterson, C., Matthews, M.D., \& Kelly, D. R. Grit: Perseverance and Passion for Long-Term Goals. Journal of Personality and Social Psychology. 2007; 92(6).

[5] Winarto, Joko T., Hayati, Elli N., Situmorang, Nina Z. Gambaran Grit Pada Mahasiswa Psikologi Profesi Universitas $X$ yang menyelesaikan Studi Tepat Waktu. Prosiding Seminar Nasional Magister Psikologi Universitas Ahmad Dahlan. 2019; Hal. 529-537.

[6] Izaach, R. N. Gambaran Derajat Grit Pada Mahasiswa Akademi Keperawatan "X" di Kabupaten Kepulauan Aru. Humanitas (Jurnal Psikologi). 2017; 1(1).

[7] Rosyadi, Ahmad Kholil \& Hermien Laksmiwati. Hubungan Antara Grit dengan Subjective WellBeing Pada Mahasiswa Psikologi Universitas Negeri Surabaya Angkatan 2017. Character: Jurnal Psikologi. 2018; 5(2).

[8] Duckworth, Angela. Grit: Kekuatan Passion dan Kegigihan. Jakarta: PT Gramedia Pustaka Utama; 2020.

[9] Brown, K. W., \& Ryan, R. M. The benefits of being present: Mindfulness and its role in psychological well-being. Journal of Personality and Social Psychology. 2003; 84(4).

[10] Deci, Edward L., Ryan, Richard M., Schultz, Patricia P.,\& Niemiec, Christopher P. Being Aware and Functioning Fully: Mindfulness and Interest Taking within Self-Determination Theory. In Brown, K. W., Creswell, J. David, 
Ryan, Richard M. (ed). Handbook of Mindfulness: Theory, Research, and Practice (pp:112-129). New York: The Guilford Press; 2015.

[11] McCarthy, J. J. Exploring the Relationship between Goal Achievement Orientation and Mindfulness in Collegiate Athletics. Journal of Clinical Sport Psychology. 2011; 5(1), 44-57.

[12] Munoz, R. T., Hoppes, S., Hellman, C. M., Brunk, K. L., Bragg, J. E., \& Cummins, C. The Effects of Mindfulness Meditation on Hope and Stress. Research on Social Work Practice. 2018; 28(6), 696- 707.

[13] Black, David S. Mindfulness Training for Children and Adolescents: A State-of-theScience Review. In Brown, K. W., Creswell, J. David, Ryan, Richard M. (ed). Handbook of Mindfulness: Theory, Research, and Practice (pp:283-310). New York: The Guilford Press; 2015.

[14] Ryan, R. M., \& Deci, E. L. Self-determination theory and the facilitation of intrinsic motivation, social development, and well-being. American Psychologist. 2000; 55(1), 68-78.

[15] K., Aidil Aryanto. Pembedaan Kadar Grit Pada Mahasiswa Universitas Hasanuddin Ditinjau dari Academic Locus of Controlnya [skripsi]. Makassar: FK, Psikologi, Universitas Hasanuddin; 2020.

[16] Kabat-Zinn, J. Mindfulness. Mindfulness. 2015; 6(6), 1481-1483.

[17] Leland, Matt. Mindfulness and Student Success. Journal of Adult Education. 2015; 44(1).

[18] Bränström, R., Duncan, L. G., \& Moskowitz, J. T. The association between dispositional mindfulness, psychological well-being, and perceived health in a Swedish population-based sample. British Journal of Health Psychology. $2011 ; 16(2)$.

[19] Suhadianto \& Arifiana, Isrida Yul. Bagaimana Mindfulness Mahasiswa Universitas X?: Pengujian Deskriptif Dan Komparatif. Prosiding Seminar Nasional dan Call Paper "Psikologi Positif Menuju Mental Wellness"; 2020.
[20] Nurida, U., Widyasari, P. Impulsivitas Siswa Sekolah Menengah: Peran Mindfulness dan SelfControl. Jurnal Psikologi Insight. 2020; 4(1), 114.

[21] Baer, Ruth A. Gregory T. Smith, Emily Lykins, Daniel Button, Jennifer Krietemeyer, Shannon Sauer, \& Erin Walsh. Construct Validity of the Five Facet Mindfulness Questionnaire in Meditating and Nonmeditating Samples. Assessment. 2008; 15(3).

[22] Snyder, C. R. Handbook of hope: Theory, measures, and applications. San Diego, CA: Academic Press; 2000.

[23] Bandura, Albert. Self-efficacy - The Exercise of Control, New York: W.H. Freeman and Company; 1997.

[24] Raphiphatthana, Buaphrao. Investigation into the relationship between mindfulness and grit, and the role of meditation experience in the relationship across cultures [thesis]. Wellington: Victoria University of Wellington; 2018.

[25] Raphiphatthana, B., Jose, P.E. \& Chobthamkit, P. The Association Between Mindfulness and Grit: an East vs. West Cross-cultural Comparison. Mindfulness. 2019; 10, 146-158.

[26] Vela, J. C., Smith, W. D., Whittenberg, J. F., Guardiola, R., \& Savage, M. Positive psychology factors as predictors of Latina/o college students' psychological grit. Journal of Multicultural Counseling and Development. 2018; 46(1).

[27] Rusadi, R.M., Sugara, G.S. \& Isti'adah, F. N. Effect of mindfulness-based cognitive therapy on academic grit among university student. Curr Psychol. 2021; doi:10.1007/s12144-021-017954

[28] Jannah, Siti Roudhotul. Hubungan Optimisme dan Grit Pada Mahasiswa yang Berwirausaha di Universitas Negeri Semarang [skripsi]. Semarang: FIP, Psikologi, Universitas Negeri Semarang; 2020.

[29] Amrullah, Muhammad Afif. "Hubungan Antara Grit Dengan Penyesuaian Diri pada Mahasiswa Tahun Pertama"[skripsi]. Surabaya: FPsi, Psikologi, Universitas Airlangga, Surabaya; 2019. 